\title{
Selection of common bean lines with high agronomic performance and high calcium and iron concentrations
}

\author{
Nerinéia Dalfollo Ribeiro(1), Lucas da Silva Domingues(2), Allan Emanoel Mezzomo Zemolin(1) \\ and Micheli Thaise Della Flora Possobom(1)
}

\begin{abstract}
(1)Universidade Federal de Santa Maria, Departamento de Fitotecnia, Avenida Roraima, no 1.000, Camobi, CEP 97105-900 Santa Maria, RS, Brazil. E-mail: nerineia@hotmail.com, allan_zemolin@hotmail.com, michepossobom@yahoo.com.br (2)Universidade Tecnológica Federal do Paraná, Campus Dois Vizinhos, Estrada Boa Esperança, Km 04, Caixa Postal 157, CEP 85660-000 Dois Vizinhos, PR, Brazil. E-mail: lucassdomingues@hotmail.com
\end{abstract}

\begin{abstract}
The objective of this work was to evaluate the genetic variability of common bean lines for cycle, weight of 100 grains, grain yield, cooking time, and grain calcium and iron concentrations. Twenty-four common bean lines were evaluated in two crop cycles (2010 and 2011). The $\bar{Z}$ index was used for the selection of superior lines for most of the traits. The DF 06-19, DF 06-03, DF 06-17, DF 06-20, DF 06-11, DF 06-14, DF 06-01, DF 06-08, DF 06-22, and DF 06-04 lines showed high grain yield. All lines were of semi-early cycle and of fast cooking. The DF 06-08 and DF 06-23 lines showed high calcium concentration in grains $\left(>1.4 \mathrm{~g} \mathrm{~kg}^{-1} \mathrm{dry}^{-}\right.$ matter - DM), and the DF 06-09, DF 06-03, DF 06-04, and DF 06-06 lines presented high iron concentration in grains $\left(>0.95 \mathrm{~g} \mathrm{~kg}^{-1} \mathrm{DM}\right)$ in the two crop cycles. The DF 06-09 and DF 06-03 carioca lines present high agronomic performance and high iron concentration in grains. The DF 06-17 and DF 06-08 black lines present high agronomic performance and high calcium concentration in grains. The selection of the DF 06-09, DF 06-03, DF 06-17, and DF 06-08 lines is recommended.
\end{abstract}

Index terms: Phaseolus vulgaris, cooking time, genetic variability, genotype $\mathrm{x}$ environment interaction, nutritional quality, $\bar{Z}$ index.

\section{Seleção de linhagens de feijão com alto desempenho agronômico e elevadas concentrações de cálcio e ferro}

Resumo - O objetivo deste trabalho foi avaliar a variabilidade genética de linhagens de feijão para ciclo, massa de 100 grãos, produtividade de grãos, tempo de cozimento e concentração de cálcio e ferro nos grãos. Vinte e quatro linhagens de feijão foram avaliadas em dois ciclos de cultura (2010 e 2011). O índice $\bar{Z}$ foi usado para a seleção de linhagens superiores, para a maioria dos caracteres. As linhagens DF 06-19, DF 06-03, DF 06-17, DF 06-20, DF 06-11, DF 06-14, DF 06-01, DF 06-08, DF 06-22 e DF 06-04 apresentaram alta produtividade de grãos. Todas as linhagens foram de ciclo semiprecoce e de rápido cozimento. As linhagens DF 06-08 e DF 06-23 apresentaram alta concentração de cálcio nos grãos ( $>1,4 \mathrm{~g} \mathrm{~kg}^{-1}$ de matéria seca - MS), e as linhagens DF 06-09, DF 06-03, DF 06-04 e DF 06-06 apresentaram alta concentração de ferro nos grãos $\left(>0,95 \mathrm{~g} \mathrm{~kg}^{-1}\right.$ de MS), nos dois anos agrícolas. As linhagens do grupo carioca DF 06-09 e DF 06-03 apresentam alto desempenho agronômico e alta concentração de ferro nos grãos. As linhagens do grupo preto DF 06-17 e DF 06-08 apresentam alto desempenho agronômico e alta concentração de cálcio nos grãos. A seleção das linhagens DF 06-09, DF 06-03, DF 06-17 e DF 06-08 é recomendada.

Termos para indexação: Phaseolus vulgaris, tempo de cozimento, variabilidade genética, interação genótipo x ambiente, qualidade nutricional, índice $\bar{Z}$.

\section{Introduction}

Nutritional deficiencies of calcium and iron can be minimized by biofortification, which is the process of increasing the concentration of bioavailable essential elements in the edible parts of plants by genetic improvement (Welch \& Graham, 2004; White \& Broadley, 2005). Common bean is the legume with the highest volume of grains consumed worldwide, and is the main source of dietary protein in many countries of Latin America and East/South Africa (Broughton et al., 2003); therefore, improvement by biofortification is a promising strategy for this species.

Genetic variability for mineral concentrations was observed in 1,150 bean accessions at International Center for Tropical Agriculture (CIAT), and the highest

Pesq. agropec. bras., Brasília, v.48, n.10, p.1368-1375, out. 2013

DOI: $10.1590 / \mathrm{S} 0100-204 X 2013001000008$ 
concentrations of calcium $\left(6.45 \mathrm{~g} \mathrm{~kg}^{-1}\right.$ dry matter $\mathrm{DM})$ and of iron $\left(0.96 \mathrm{~g} \mathrm{~kg}^{-1} \mathrm{DM}\right)$ were found in wild accessions (Beebe et al., 2000). Cultivated accessions of bean grown in Brazil presented calcium values from 0.30 to $2.80 \mathrm{~g} \mathrm{~kg}^{-1} \mathrm{DM}$ and iron values from 0.71 to $1.27 \mathrm{~g} \mathrm{~kg}^{-1} \mathrm{DM}$ (Mesquita et al., 2007).

Narrow-sense heritability of calcium concentration in common bean grains of Middle American origin ranged from intermediate $\left(h^{2} r=47 \%\right)$ to high $\left(h^{2} r=63.61 \%\right)$, and the predominance of additive genetic effects was reported in early generations (Jost et al., 2009b). These authors found an increase of $33.64 \%$ in calcium concentration in common bean grains. Therefore, the performance of crosses and selection of recombinants are a promising strategy for the selection of common bean lines with high calcium concentration in grains.

Iron concentration in bean grains presented continuous distribution among $77 \mathrm{~F}_{5: 7}$ lines (Cichy et al., 2009), $87 \mathrm{~F}_{7: 11}$ lines (Blair et al., 2009), and $110 \mathrm{~F}_{10}$ lines (Blair et al., 2010), indicating that this trait showed quantitative inheritance in a different gene pool. Estimates of narrow-sense heritability for iron concentration in common bean grains were obtained in early generations, ranging from intermediate $\left(h^{2} r=50.60 \%\right)$ to high $\left(h^{2} r=98.93 \%\right)$ (Jost et al., 2009a). The authors obtained $F_{2}$ plants with a $94 \%$ increase in iron concentration in common bean grains, indicating great prospects of success in developing biofortified common bean cultivars.

The identification of inbred common bean lines of the Middle American gene pool with high calcium and iron concentrations in grains and high agronomic performance are unprecedented in the literature. When selection is performed for many traits simultaneously, the use of selection indices must be taken into consideration. The $\bar{Z}$ index considers the sum of standardized variables for each plot (Mendes et al., 2009). Lines with the highest $\bar{Z}$ index sums are considered promising for selection, because they have presented superiority for most of the desirable traits.

The objective of this work was to evaluate the genetic variability of common bean lines for cycle, weight of 100 grains, grain yield, cooking time, and grain calcium and iron concentrations.

\section{Materials and Methods}

Inbred lines were obtained from crosses between contrasting cultivars of Common bean (Phaseolus vulgaris L.), for grain yield and calcium (Pérola $\mathrm{x}$ TPS Bonito and TPS Bonito $x$ BRS Expedito) and for grain yield and iron concentrations in grains (Minuano $\mathrm{x}$ Diamante Negro and Diamante Negro x Iapar 44) (Jost et al., 2009a, 2009b). These crossings were performed at Universidade Federal de Santa Maria (UFSM), in the state of Rio Grande do Sul, Brazil, and the segregating generations were advanced from $F_{2}$ to $F_{7}$ as described by Jost et al. (2013). In the $\mathrm{F}_{8}$ generation, 20 inbred lines were selected based on high grain yield, and these lines were evaluated for agronomic performance and calcium and iron concentrations. Two field experiments were carried out in normal rainy season (sowing in October), in two consecutive years: 2010 and 2011. The meteorological data of the two crop years are shown in Table 1. All field experiments were conducted in the experimental area of the bean breeding program of the Department of Plant Sciences of UFSM, in the Central Depression region of the state of Rio Grande do Sul, South Brazil (29 $42^{\prime} \mathrm{S}, 53^{\circ} 49^{\prime} \mathrm{W}$, at $95 \mathrm{~m}$ altitude). The climate type is temperate and rainy, with well-distributed rainfall throughout the year and subtropical temperatures.

The experiment was carried out in a randomized complete block design with three replicates. Plots consisted of four $4 \mathrm{~m}$ long rows, spaced $0.50 \mathrm{~m}$ apart, and useable area of $4 \mathrm{~m}^{2}$. Treatments consisted of the evaluation of 24 inbred common bean lines of the Middle American gene pool with grains of carioca and black teguments, as follows: $20 \mathrm{~F}_{8}$ lines (DF 06-09, DF 06-19, DF 06-03, DF 06-17, DF 06-25, DF 06-20, DF 06-11, DF 06-14, DF 06-13, DF 06-01, DF 06-08, DF 06-22, DF 06-04, DF 06-06, DF 06-02, DF 06-16, DF 06-12, DF 06-07, DF 06-23, and DF 06-24) and four control cultivars (BRS Valente, Guapo Brilhante, Carioca, and Pérola), which are commercial cultivars registered for cultivation in southern Brazil. These $\mathrm{F}_{8}$ lines were advanced using the pedigree and single-seed descent methods and were selected for high grain yield and calcium and iron concentrations by Jost et al. (2013).

The soil of the experimental area is a typical alitic Argisol (Hapludalf) (Argissolo Vermelho, Santos et al., 2006), with the following chemical composition, in 2010: $\mathrm{pH}\left(\mathrm{H}_{2} \mathrm{O}\right)$ of 5.7; $20 \mathrm{~g} \mathrm{~kg}^{-1}$ organic matter; $4.5 \mathrm{mg} \mathrm{dm}{ }^{-3} \mathrm{P} ; 112 \mathrm{mg} \mathrm{dm}{ }^{-3} \mathrm{~K} ; 6.3 \mathrm{cmol}_{\mathrm{c}} \mathrm{dm}^{-3} \mathrm{Ca}$; and $2.8 \mathrm{cmol}_{\mathrm{c}} \mathrm{dm}^{-3} \mathrm{Mg}$. Soil was prepared in a conventional manner, and fertilization was performed in two times based on soil chemical analysis. Fertilizer used at furrow sowing was $250 \mathrm{~kg} \mathrm{ha}^{-1}$ of the formula

Pesq. agropec. bras., Brasília, v.48, n.10, p.1368-1375, out. 2013 DOI: $10.1590 / \mathrm{S} 0100-204 X 2013001000008$ 
5-30-20 (urea: $45 \% \mathrm{~N}$, superphosphate: $18 \% \mathrm{P}_{2} \mathrm{O}_{5}$, and potassium chloride: $60 \% \mathrm{~K}_{2} \mathrm{O}$ ). In addition, nitrogen fertilization was split at $20 \mathrm{~kg} \mathrm{ha}^{-1}$ urea $(45 \% \mathrm{~N})$ in the growth stage of the first trifoliate leaf (V3) (Fernández et al., 1986). Micronutrients were not added to the fertilizer.

In 2011, an experiment was performed in the same experimental area. Fertilization was calculated based on the amount of nutrient exported by the crop, more than is necessary for the growth and development of the culture. The fertilizer used at sowing was $250 \mathrm{~kg} \mathrm{ha}^{-1}$ of the 5-30-20 formula, and $20 \mathrm{~kg} \mathrm{ha}^{-1}$ of urea was split in the growing stage of the first trifoliate leaf (V3). Insect and weed control was carried out whenever necessary to rule out competition. Disease control was not performed.

The cycle - number of days from emergence to maturity - was evaluated when half plus one of the plants in the useful area reached stage R9 (maturation), characterized according to the phenological scale presented by Fernández et al. (1986). Plants from the useable area were harvested and threshed by hand when mature. After manual removal of broken grains and impurities, the grains were dried in a drying and sterilization oven with forced air circulation $\left(65-70^{\circ} \mathrm{C}\right)$ (Odontobras 1.5, Odontobras, Ribeirão Preto, SP, Brazil) until they reached an average moisture content of $13 \%$. The weight of 100 grains $(\mathrm{g})$ and grain yield $\left(\mathrm{kg} \mathrm{ha}^{-1}\right)$ were determined.

Cooking time was evaluated with 25 grains of each replicate. Grains were put in $200 \mathrm{~mL}$ plastic cups, to which $50 \mathrm{~mL}$ distilled water were added. After 8 hours of imbibition at room temperature $\left(20 \pm 2^{\circ} \mathrm{C}\right)$, water was eliminated and grains were partially dried with a paper towel and placed on the support plate of a Mattson cooker (Embrapa Instrumentação, São Carlos, SP, Brazil), according to the methodology described by Rodrigues et al. (2005a). The device has 25 pegs of $90 \mathrm{~g}$, with $1.0 \mathrm{~mm}$ of diameter at the tip. Each grain was positioned under a peg and the device was placed inside of a domestic $7 \mathrm{~L}$ pressure pan, filled with $3 \mathrm{~L}$ of boiling distilled water. The pan was kept overheating (with no lid) at medium fire, and, when the grain was cooked, the peg fell and perforated the grain. The average time it took for the first 13 pegs to fall was registered as the cooking average time of each sample (Ribeiro et al., 2007).

A homogeneous sample of $150 \mathrm{~g}$ of grains of two replicates was obtained for each line in each year. For determination of mineral concentrations, $10 \mathrm{~g}$ grain samples from each line were randomly collected from each replicate. Samples were oven-dried $\left(65\right.$ to $\left.70^{\circ} \mathrm{C}\right)$ until they reached an average moisture content of $13 \%$ and were weighed. Samples were ground in an analytical knife micro-mill (Q298A21, Quimis, Diadema, SP, Brazil) to produce particles smaller than $1 \mathrm{~mm}$.

A sample of $0.5 \mathrm{~g}$ of raw bean flour was digested with nitric and perchloric acid $\left(\mathrm{HNO}_{3}+\mathrm{HClO}_{4}\right.$ at a 3:1 ratio by volume). After 12 hours of cold digestion, hot digestion was performed according to Miyazawa et al. (1999). Calcium and iron concentrations were performed by atomic absorption spectrophotometer (Xplor AA, GBC Scientific Equipment Pty. Ltd., Braeside, Australia), using a wavelength of 422.70 and $248.3 \mathrm{~nm}$, respectively.

Obtained data were subjected to analysis of variance, according to the random block model, except cooking time and calcium and iron concentrations, which were analyzed in a completely randomized design. The Bartlett test was applied to check homogeneity of the variances of errors found for the two crop years. The $\mathrm{F}$ test, at 5\% probability, was used to test the hypotheses of main effects and interactions of line x year. Effects of lines were considered fixed and those of block, year, and interaction, random. Comparison of means between the lines was done using the Scott \& Knott test, at $5 \%$ probability.

Data were standardized by plot, allowing them to be directly comparable. The selection index ( $\bar{Z}$ index) was estimated for $Z_{i j}=\left(Y_{i j}-Y_{j}\right) / S_{j}$, in which $Z_{i j}$ is the value

Table 1. Meteorological data collected at the weather station installed at Universidade Federal de Santa Maria $\left(29^{\circ} 42^{\prime} \mathrm{S}\right.$, $53^{\circ} 49^{\prime} \mathrm{W}$, at $95 \mathrm{~m}$ altitude), state of Rio Grande do Sul, Brazil.

\begin{tabular}{|c|c|c|c|c|c|c|c|c|}
\hline \multirow[t]{2}{*}{ Variable } & \multicolumn{4}{|c|}{ Normal rainy season 2010} & \multicolumn{4}{|c|}{ Normal rainy season 2011} \\
\hline & October & November & December & January & October & November & December & January \\
\hline Maximum temperature $\left({ }^{\circ} \mathrm{C}\right)$ & 24.4 & 27.7 & 30.4 & 32.5 & 24.8 & 20.5 & 31.7 & 31.8 \\
\hline Minimum temperature $\left({ }^{\circ} \mathrm{C}\right)$ & 12.7 & 14.9 & 18.4 & 21.8 & 14.0 & 13.9 & 16.9 & 20.5 \\
\hline Rainfall (mm) & 49.3 & 71.3 & 157.9 & 127.1 & 184.8 & 41.6 & 13.4 & 139.1 \\
\hline
\end{tabular}


of the standardized trait of $i$ lines $(i=1,2, \ldots 24)$, in $\mathrm{j}$ replicate $(j=1,2,3)$; $Y_{i j}$ is the observation for the trait of $i$ lines in $j$ replicate; $Y_{j}$ is the overall average for the trait of 24 lines in $\mathrm{j}$ replicate; and $\mathrm{S}_{\mathrm{j}}$ is the standard deviation for the trait in $\mathrm{j}$ replicate, adapted from Mendes et al. (2009). However, since the traits were determined using a different number of replicates, the $\bar{Z}$ index mean was considered for those traits present in $\mathrm{j}$ replicate, and a constant with a value of seven was added to avoid negative values. Charts were marked to check the contribution given by each standardized trait for $\bar{Z}$ index value, facilitating the visual identification among lines with higher $\bar{Z}$ index mean for all traits, according to Mendes et al. (2009). Analyses and mean test were carried out with the Genes software (Viçosa, MG, Brazil), and the $\bar{Z}$ index and charts were performed on Microsoft Office Excel spreadsheets.

\section{Results and Discussion}

The variance of the experimental error for the two crop years was homogeneous, making a joint variance analysis possible for all evaluated traits. Variance analysis showed a significant line $\mathrm{x}$ year interaction in relation to weight of 100 grains, grain yield, cooking time, and calcium concentration in grains, indicating a differential effect of common bean lines due to environmental variation (Table 2). Significant line x environment interaction was also previously observed for grain yield (Ribeiro et al., 2008; Perina et al., 2010), for cooking time (Rodrigues et al., 2005a), and for calcium concentration in bean grains (Jost et al., 2010). In the present work, cycle and grain iron concentrations were significant only for lines. For cycles, a significant effect for crop years was observed.
In this case, genetic variability was found among lines, allowing the selection of superior common bean lines.

Cycles ranged from 72 (DF 06-25) to 78 days (DF 06-01) (Table 3). Early-cycle bean cultivars require about 70 days for harvesting, but few are registered in the National Register of Cultivars, in Brazil (Brasil, 2012). Therefore, all the evaluated lines can be considered of semi-early cycle and meet the demands of rural producers. The identification of common bean lines with an early cycle allows planning harvests for periods of less rain, the reduction of water consumption by irrigated crops, and the early freeing of the area for crop succession (Buratto et al., 2007).

Most lines showed weight of 100 grains lower than $25 \mathrm{~g}$ (Table 3), of small size according to the classification of Blair et al. (2010). However, it was possible to identify lines of the Middle American gene pool with carioca tegument and medium grains

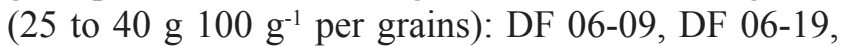
DF 06-03, DF 06-25, DF 06-14, and Pérola. Since in Brazil there is a great demand for black and carioca grain teguments, the selection of lines with smalland medium-sized grains could meet the demands of consumers who prefer grains from different classes.

In 2010, the Scott \& Knott test was used to develop stratifications into two groups of lines, regarding grain yield: intermediate $\left(1,883\right.$ to $\left.2,361 \mathrm{~kg} \mathrm{ha}^{-1}\right)$ and high (2,387 to $\left.3,223 \mathrm{~kg} \mathrm{ha}^{-1}\right)$ (Table 3$)$. In 2011, two groups of lines were formed: intermediate $(1,673$ to $\left.2,412 \mathrm{~kg} \mathrm{ha}^{-1}\right)$ and high $\left(2,578\right.$ to $\left.3,290 \mathrm{~kg} \mathrm{ha}^{-1}\right)$. Since a significant line $\mathrm{x}$ year interaction was only observed for grain yield (Table 2), not all lines that presented high grain yield in 2010 were the best in 2011 (Table 3). Similar results were observed for grain yield of common bean lines evaluated in different environments (Ribeiro et al., 2008; Perina et al., 2010). However, in

Table 2. Degrees of freedom (DF) and mean square (MS) of joint variance analysis for number of days from emergence to maturity (cycle), weight of 100 grains (g), grain yield ( $\left.\mathrm{kg} \mathrm{ha}^{-1}\right)$, cooking time (s), calcium concentration $\left(\mathrm{g} \mathrm{kg}^{-1}\right.$ dry matter $\mathrm{DM})$, and iron concentration in grains $\left(\mathrm{g} \mathrm{kg}^{-1} \mathrm{DM}\right)$ of common bean lines evaluated in two crop years.

\begin{tabular}{lccccccc}
\hline Source of variation & DF & \multicolumn{5}{c}{ Mean square } \\
\cline { 3 - 7 } & & Cycle & Weight & Yield & Cooking time & Calcium & Iron \\
\hline Block / year & 2 & 0.9 & 3.9 & $416,369.8$ & - & - \\
Lines (L) & 23 & $16.0^{*}$ & $60.7^{*}$ & $492,850.7^{\text {ns }}$ & $21,823.5^{\text {ns }}$ & $0.1^{*}$ & $462.7^{*}$ \\
Years (Y) & 1 & $1,653.8^{*}$ & $50.4^{\text {ns }}$ & $994,499.3^{\text {ns }}$ & $1,384,348.3^{*}$ & $1.8^{*}$ & $177.4^{\text {ns }}$ \\
L x Y & 23 & $2.7^{\text {ns }}$ & $4.4^{*}$ & $392,318.1^{*}$ & $27,655.9^{*}$ & $0.1^{*}$ & $136.1^{\text {ns }}$ \\
Error & 92 & 2.5 & 1.3 & $161,321.1$ & $7,533.3$ & 0.6 & 209.8 \\
\hline Mean & - & 74.1 & 22.4 & $2,499.0$ & 17.39 & 1.2 & 0.82 \\
CV (\%) & - & 2.1 & 5.0 & 16.1 & 8.2 & 20.1 & 17.6 \\
\hline
\end{tabular}

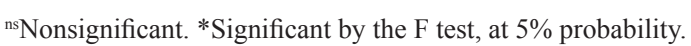


the present study, the DF 06-19, DF 06-03, DF 06-17, DF 06-20, DF 06-11, DF 06-14, DF 06-01, DF 06-08, DF 06-22, and DF 06-04 lines showed high grain yield in both crop years. No cultivar control presented high grain yield in two consecutive years. However, these lines are promising for selection by breeding programs, since they had the highest grain yield in a year of high precipitation during the grain-filling period to harvest (2010) and of low rainfall in the same sub-period (2011) (Table 1). In 2011, 70\% of average rainfall volume was recorded after harvest. In a climate change scenario, the identification of common bean lines that maintain high grain yield under phenomena such as El niño and La niña certainly have great importance for crop sustainability.

Cooking time was different for common bean lines in different crop years (Table 4). In 2010, cooking time varied from $17 \mathrm{~min}$ and $13 \mathrm{~s}$ (BRS Valente) to $23 \mathrm{~min}$ and $5 \mathrm{~s}$ (DF 06-17). In 2011, the lines with reduced cooking time were: DF 06-09, DF 06-19, DF 06-03,
DF 06-17, DF 06-20, DF 06-11, DF 06-14, DF 06-13, DF 06-01, DF 06-08, DF 06-22, DF 06-04, DF 06-02, DF 06-16, DF 06-12, DF 06-23, Guapo Brilhante, and Carioca; Pérola presented the highest cooking time (20 min and $22 \mathrm{~s}$ ). Rodrigues et al. (2005a) found that the cooking time of TPS Nobre and Pérola cultivars varied from $15 \mathrm{~min}$ and $24 \mathrm{~s}$ to $20 \mathrm{~min} 37 \mathrm{~s}$ in different growing seasons. According to these authors, the environmental conditions during harvest, especially the amount of precipitation, affected bean cooking time. Considering that common bean cultivars with cooking time of less than $30 \mathrm{~min}$ are desirable because it means saving energy and costs (Rodrigues et al., 2005b), all lines evaluated in the present study meet consumers' expectations.

In 2010, the common bean lines were classified in two groups for grain calcium concentration: group 1 (0.7 to $1.3 \mathrm{~g} \mathrm{~kg}^{-1} \mathrm{DM}$ ) and group 2 (1.4 to $1.8 \mathrm{~g} \mathrm{~kg}^{-1} \mathrm{DM}$ ) (Table 4). In 2011, three groups were formed: group 1 (0.7 to $1.1 \mathrm{~g} \mathrm{~kg}^{-1} \mathrm{DM}$ ), group 2 (1.2 to $1.4 \mathrm{~g} \mathrm{~kg}^{-1} \mathrm{DM}$ ),

Table 3. Number of days from emergence to maturity (cycle), weight of 100 grains, and grain yield of common bean lines of the black (B) and carioca (C) groups, evaluated in two crop years ${ }^{(1)}$.

\begin{tabular}{|c|c|c|c|c|c|c|}
\hline \multirow[t]{2}{*}{ Line } & \multirow[t]{2}{*}{ Group } & \multirow{2}{*}{$\begin{array}{c}\text { Cycle mean } \\
\text { (day) }\end{array}$} & \multicolumn{2}{|c|}{ Weight of 100 grains (g) } & \multicolumn{2}{|c|}{ Grain yield $\left(\mathrm{kg} \mathrm{ha}^{-1}\right)$} \\
\hline & & & 2010 & 2011 & 2010 & 2011 \\
\hline DF 06-09 & $\mathrm{C}$ & $74.0 \mathrm{c}$ & $27.3 \mathrm{c}$ & $23.7 \mathrm{c}$ & $3,223 a$ & $2,153 b$ \\
\hline DF 06-19 & $\mathrm{C}$ & $73.2 \mathrm{~d}$ & $31.3 \mathrm{a}$ & $26.3 b$ & $2,893 a$ & $3,097 \mathrm{a}$ \\
\hline DF 06-03 & $\mathrm{C}$ & $77.0 \mathrm{a}$ & $27.1 \mathrm{c}$ & $24.6 \mathrm{c}$ & $2,726 a$ & $2,578 \mathrm{a}$ \\
\hline DF 06-17 & $\mathrm{B}$ & $73.3 \mathrm{c}$ & $20.9 \mathrm{e}$ & $19.4 d$ & $2,723 \mathrm{a}$ & $2,593 a$ \\
\hline DF $06-25$ & $\mathrm{C}$ & $72.0 \mathrm{~d}$ & $30.2 \mathrm{a}$ & $28.9 \mathrm{a}$ & $2,617 \mathrm{a}$ & $1,821 b$ \\
\hline DF 06-20 & $\mathrm{B}$ & $73.0 \mathrm{~d}$ & $20.8 \mathrm{e}$ & $20.5 d$ & $2,609 \mathrm{a}$ & $2,787 \mathrm{a}$ \\
\hline DF $06-11$ & B & $73.8 \mathrm{c}$ & $20.6 \mathrm{e}$ & $20.9 d$ & $2,601 \mathrm{a}$ & $3,290 \mathrm{a}$ \\
\hline DF 06-14 & $\mathrm{C}$ & $73.8 \mathrm{c}$ & $28.4 \mathrm{~b}$ & $23.5 \mathrm{c}$ & $2,552 \mathrm{a}$ & $2,691 \mathrm{a}$ \\
\hline DF 06-13 & $\mathrm{B}$ & $73.8 \mathrm{c}$ & $19.9 \mathrm{f}$ & $20.0 \mathrm{~d}$ & $2,503 \mathrm{a}$ & $2,336 b$ \\
\hline DF 06-01 & B & $78.0 \mathrm{a}$ & $19.9 \mathrm{f}$ & $20.2 d$ & $2,485 \mathrm{a}$ & $2,695 \mathrm{a}$ \\
\hline DF 06-08 & B & $74.2 \mathrm{c}$ & $19.4 \mathrm{f}$ & $20.7 d$ & $2,463 \mathrm{a}$ & $2,863 a$ \\
\hline Pérola & $\mathrm{C}$ & $72.8 \mathrm{~d}$ & $28.3 b$ & $26.6 b$ & $2,435 \mathrm{a}$ & $1,699 b$ \\
\hline DF 06-22 & B & $72.7 \mathrm{~d}$ & $21.9 \mathrm{e}$ & $20.7 d$ & $2,414 a$ & $2,818 \mathrm{a}$ \\
\hline DF 06-04 & B & $76.3 b$ & $20.1 \mathrm{f}$ & $19.1 d$ & $2,387 \mathrm{a}$ & $3,175 \mathrm{a}$ \\
\hline DF 06-06 & B & $74.7 \mathrm{c}$ & $19.3 f$ & $19.8 \mathrm{~d}$ & $2,361 b$ & $2,888 \mathrm{a}$ \\
\hline DF 06-02 & $\mathrm{B}$ & $77.7 \mathrm{a}$ & $20.7 \mathrm{e}$ & $19.1 \mathrm{~d}$ & $2,334 b$ & $2,636 a$ \\
\hline DF 06-16 & $\mathrm{B}$ & $73.3 \mathrm{c}$ & $19.1 \mathrm{f}$ & $20.3 \mathrm{~d}$ & $2,274 b$ & $2,210 \mathrm{~b}$ \\
\hline DF 06-12 & B & $73.8 \mathrm{c}$ & $19.1 \mathrm{f}$ & $20.4 d$ & $2,264 b$ & $3,037 \mathrm{a}$ \\
\hline DF 06-07 & $\mathrm{C}$ & $74.2 \mathrm{c}$ & $25.1 \mathrm{~d}$ & $24.2 \mathrm{c}$ & $2,184 b$ & $2,412 b$ \\
\hline DF 06-23 & B & $72.5 \mathrm{~d}$ & $21.5 \mathrm{e}$ & $21.5 \mathrm{~d}$ & $2,085 b$ & $2,936 a$ \\
\hline Guapo Brilhante & B & $75.3 b$ & $21.8 \mathrm{e}$ & $19.4 d$ & $2,056 \mathrm{~b}$ & $2,771 \mathrm{a}$ \\
\hline DF 06-24 & B & $72.2 d$ & $21.5 \mathrm{e}$ & $19.8 \mathrm{~d}$ & $2,025 b$ & $2,584 a$ \\
\hline Carioca & $\mathrm{C}$ & $73.5 \mathrm{c}$ & $25.0 \mathrm{~d}$ & $23.3 \mathrm{~d}$ & $1,885 b$ & $1,673 b$ \\
\hline BRS Valente & $\mathrm{B}$ & $73.8 \mathrm{c}$ & $22.6 \mathrm{e}$ & $20.6 \mathrm{~d}$ & $1,883 \mathrm{~b}$ & $2,230 \mathrm{~b}$ \\
\hline Mean & - & 74.12 & 23.0 & 21.8 & 2,416 & 2,582 \\
\hline CV $(\%)$ & - & 2.12 & 4.71 & 5.32 & 13.46 & 18.03 \\
\hline
\end{tabular}

${ }^{(1)}$ Means followed by equal letters, in the columns, do not differ by the Scott \& Knott test, at $5 \%$ probability. 
and group 3 (1.7 $\left.\mathrm{g} \mathrm{kg}^{-1} \mathrm{DM}\right)$. These calcium values were similar to those obtained in carioca and black tegument bean grains of Middle American recombinant lines, ranging from 0.58 to $1.47 \mathrm{~g} \mathrm{~kg}^{-1} \mathrm{DM}$ (Jost et al., 2009b), and in grains of 29 Andean lines with different tegument colors, cultivated in Brazil, the United States, and in Colombia, varying from 0.58 to $1.22 \mathrm{~g} \mathrm{~kg}^{-1} \mathrm{DM}$ (Akond et al., 2011).

Based on data obtained in the present study, the following classification is proposed for calcium concentration in bean grains: low $\left(<0.7 \mathrm{~g} \mathrm{~kg}^{-1}\right.$ $\mathrm{DM}$ ), intermediate ( 0.8 to $\left.1.3 \mathrm{~g} \mathrm{~kg}^{-1} \mathrm{DM}\right)$, and high $\left(>1.4 \mathrm{~g} \mathrm{~kg}^{-1} \mathrm{DM}\right)$. Therefore, common bean lines with calcium concentration superior to $1.4 \mathrm{~g} \mathrm{~kg}^{-1} \mathrm{DM}$ should be considered of high nutritional value because the calcium values are greater than those previously

Table 4. Cooking time and calcium and iron concentration in grains ( $\mathrm{g} \mathrm{kg}^{-1}$ dry matter) of common bean lines of the black (B) and carioca (C) groups, evaluated in two crop years ${ }^{(1)}$.

\begin{tabular}{|c|c|c|c|c|c|c|}
\hline \multirow[t]{2}{*}{ Line } & \multicolumn{3}{|c|}{ Group Cooking time (min) } & \multicolumn{2}{|c|}{ Calcium $\left(\mathrm{g} \mathrm{kg}^{-1}\right)$} & \multirow{2}{*}{$\begin{array}{c}\text { Iron mean } \\
\left(\mathrm{g} \mathrm{kg}^{-1}\right)\end{array}$} \\
\hline & & 2010 & 2011 & 2010 & 2011 & \\
\hline DF 06-09 & C & $20.37 b$ & $14.14 \mathrm{c}$ & $1.5 \mathrm{a}$ & $0.7 \mathrm{c}$ & $1.06 \mathrm{a}$ \\
\hline DF 06-19 & $\mathrm{C}$ & $21.40 \mathrm{a}$ & $16.05 \mathrm{c}$ & $0.7 \mathrm{~b}$ & $0.9 \mathrm{c}$ & $0.65 b$ \\
\hline DF 06-03 & $\mathrm{C}$ & $19.36 b$ & $16.23 \mathrm{c}$ & $1.1 \mathrm{~b}$ & $1.0 \mathrm{c}$ & $0.95 \mathrm{a}$ \\
\hline DF 06-17 & $\mathrm{B}$ & $23.05 \mathrm{a}$ & $15.42 \mathrm{c}$ & $1.8 \mathrm{a}$ & $1.1 \mathrm{c}$ & $0.85 \mathrm{~b}$ \\
\hline DF 06-25 & $\mathrm{C}$ & $21.01 \mathrm{a}$ & $16.56 \mathrm{~b}$ & $1.2 \mathrm{~b}$ & $1.2 \mathrm{~b}$ & $0.74 b$ \\
\hline DF $06-20$ & B & $22.53 \mathrm{a}$ & $15.11 \mathrm{c}$ & $1.3 \mathrm{~b}$ & $1.0 \mathrm{c}$ & $0.76 \mathrm{~b}$ \\
\hline DF $06-11$ & B & $18.21 \mathrm{~b}$ & $15.12 \mathrm{c}$ & $1.1 \mathrm{~b}$ & $1.0 \mathrm{c}$ & $0.80 \mathrm{~b}$ \\
\hline DF 06-14 & $\mathrm{C}$ & $19.11 \mathrm{~b}$ & $16.16 \mathrm{c}$ & $1.2 \mathrm{~b}$ & $0.7 \mathrm{c}$ & $0.73 b$ \\
\hline DF $06-13$ & B & $19.09 \mathrm{~b}$ & $15.11 \mathrm{c}$ & $1.5 \mathrm{a}$ & $0.7 \mathrm{c}$ & $0.84 \mathrm{~b}$ \\
\hline DF $06-01$ & B & $20.37 \mathrm{a}$ & $14.14 \mathrm{c}$ & $1.3 \mathrm{~b}$ & $1.1 \mathrm{c}$ & $0.79 b$ \\
\hline DF 06-08 & B & $19.33 b$ & $15.10 \mathrm{c}$ & $1.7 \mathrm{a}$ & $1.7 \mathrm{a}$ & $0.86 \mathrm{~b}$ \\
\hline Pérola & $\mathrm{C}$ & $19.26 \mathrm{~b}$ & $20.22 \mathrm{a}$ & $1.7 \mathrm{a}$ & $0.9 \mathrm{c}$ & $0.83 b$ \\
\hline DF $06-22$ & B & $16.48 \mathrm{~b}$ & $14.34 \mathrm{c}$ & $1.5 \mathrm{a}$ & $1.1 \mathrm{c}$ & $0.71 \mathrm{~b}$ \\
\hline DF 06-04 & B & $19.34 b$ & $14.36 \mathrm{c}$ & $1.3 \mathrm{~b}$ & $1.1 \mathrm{c}$ & $1.08 \mathrm{a}$ \\
\hline DF 06-06 & B & $19.45 b$ & $16.46 \mathrm{~b}$ & $1.4 \mathrm{a}$ & $0.9 \mathrm{c}$ & $1.01 \mathrm{a}$ \\
\hline DF 06-02 & B & $18.41 \mathrm{~b}$ & $15.52 \mathrm{c}$ & $1.1 \mathrm{~b}$ & $0.9 \mathrm{c}$ & $0.73 b$ \\
\hline DF 06-16 & B & $19.48 b$ & $15.16 \mathrm{c}$ & $1.6 \mathrm{a}$ & $1.0 \mathrm{c}$ & $0.78 b$ \\
\hline DF 06-12 & B & $17.36 \mathrm{~b}$ & $14.35 \mathrm{c}$ & $0.8 \mathrm{~b}$ & $1.3 b$ & $0.86 \mathrm{~b}$ \\
\hline DF 06-07 & $\mathrm{C}$ & $17.36 \mathrm{~b}$ & $17.28 \mathrm{~b}$ & $1.2 \mathrm{~b}$ & $1.0 \mathrm{c}$ & $0.80 \mathrm{~b}$ \\
\hline DF $06-23$ & B & $17.44 \mathrm{~b}$ & $16.24 \mathrm{c}$ & $1.5 \mathrm{a}$ & $1.4 \mathrm{~b}$ & $0.80 \mathrm{~b}$ \\
\hline Guapo Brilhante & B & $17.50 \mathrm{~b}$ & $16.21 \mathrm{c}$ & $1.4 \mathrm{a}$ & $1.2 \mathrm{~b}$ & $0.83 b$ \\
\hline DF 06-24 & B & $18.19 \mathrm{~b}$ & $17.08 \mathrm{~b}$ & $1.1 \mathrm{~b}$ & $1.2 \mathrm{~b}$ & $0.77 b$ \\
\hline Carioca & $\mathrm{C}$ & $17.50 \mathrm{~b}$ & $15.31 \mathrm{c}$ & $1.2 \mathrm{~b}$ & $0.9 \mathrm{c}$ & $0.72 b$ \\
\hline BRS Valente & B & $17.13 \mathrm{~b}$ & $18.01 \mathrm{~b}$ & $1.4 \mathrm{a}$ & $1.1 \mathrm{~b}$ & $0.78 \mathrm{~b}$ \\
\hline Mean & - & 19.28 & 16.01 & 1.31 & 1.04 & 0.82 \\
\hline CV (\%) & - & 8.35 & 6.76 & 16.02 & 18.71 & 17.6 \\
\hline
\end{tabular}

${ }^{(1)}$ Means followed by equal letters, in the columns, do not differ by the Scott $\&$ Knott test, at $5 \%$ probability. described in the literature (Jost et al., 2009b; Akond et al., 2011). The DF 06-08 and DF 06-23 lines presented high grain calcium concentration in the two crop years (Table 4), and the selection of these lines are indicated for biofortification programs.

A stratification of two groups of lines was observed regarding iron concentration in grains: moderate $(0.65$ to $\left.0.86 \mathrm{~g} \mathrm{~kg}^{-1} \mathrm{DM}\right)$ and high (0.95 to $1.08 \mathrm{~g} \mathrm{~kg}^{-1} \mathrm{DM}$ ) (Table 4). The DF 06-09, DF 06-03, DF 06-04, and DF 06-06 lines presented a high iron concentration in grains and are indicated for biofortification programs. Iron concentration of the DF 06-09, DF 06-03, DF 06-04, and DF 06-06 lines was equal or superior to the iron value observed in wild bean accessions with high iron concentrations from the CIAT collection (Beebe et al., 2000). However, the values obtained in the present study were similar to the iron concentrations previously described in common bean cultivars grown in Brazil, ranging from 0.71 to $1.27 \mathrm{~g} \mathrm{~kg}^{-1} \mathrm{DM}$ (Mesquita et al., 2007).

Nine lines presented the highest $\bar{Z}$ index means for all traits (Figure 1). Lines with higher $\bar{Z}$ index values for weight of 100 grains, grain yield, calcium and iron concentrations, and lower $\bar{Z}$ index values for cycle and cooking time are promising for selection. None of the lines simultaneously showed high calcium and iron concentrations. However, Silva et al. (2012) selected bean lines with high calcium and iron concentrations using the $\bar{Z}$ index. In the present study, among carioca group lines, DF 06-09 and the DF 06-03 showed the highest $\bar{Z}$ index values for grain yield, weight of 100 grains, and iron concentration in grains, and the lowest $\bar{Z}$ index values for cycle and cooking time.

Regarding lines of the black group, DF 06-17 and DF $06-08$ presented the highest $\bar{Z}$ index values for grain yield and calcium concentration in grains, and the lowest $\bar{Z}$ index values for cycle and cooking time. The black group lines with the highest average $\bar{Z}$ index showed small-sized grains, i.e., weight of 100 grains of less than $25 \mathrm{~g}$.

The lines of the carioca group (DF 06-09 and DF 06-03) and the lines of the black group (DF 06-17 and DF 06-08) were selected due to their high agronomic performance and high mineral concentration in grains. Since the selected lines from the carioca and black groups had high iron and calcium concentrations in grains, respectively, the artificial hybridizations between parents of different groups is recommended to develop common bean lines more nutritionally complete.

Pesq. agropec. bras., Brasília, v.48, n.10, p.1368-1375, out. 2013 DOI: $10.1590 / \mathrm{S} 0100-204 \mathrm{X} 2013001000008$ 
DF 06-25

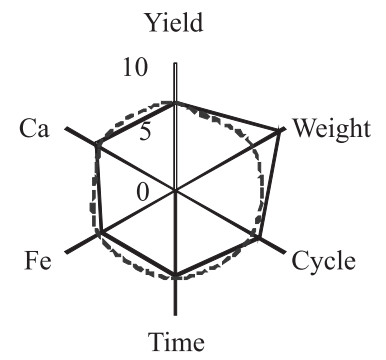

DF 06-19

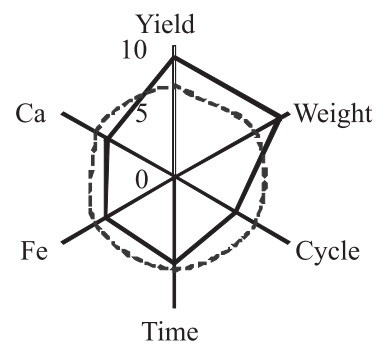

DF 06-17

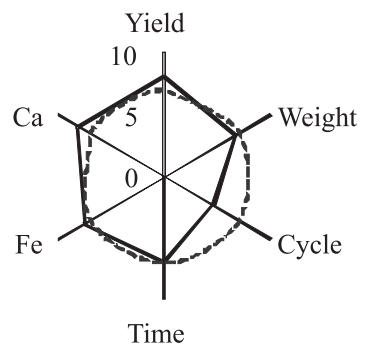

Pérola

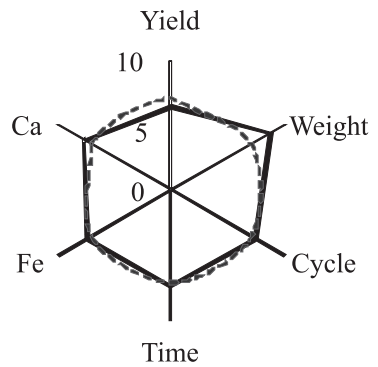

DF 06-03

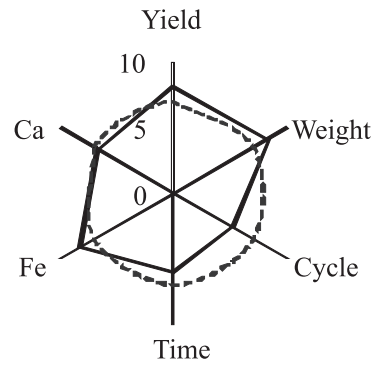

DF 06-20

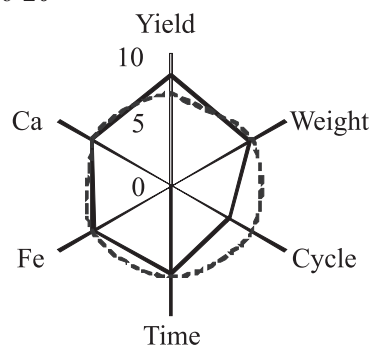

DF 06-09

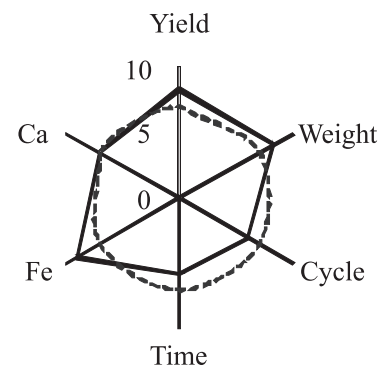

DF $06-22$

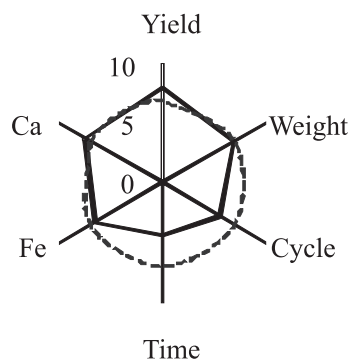

DF 06-08

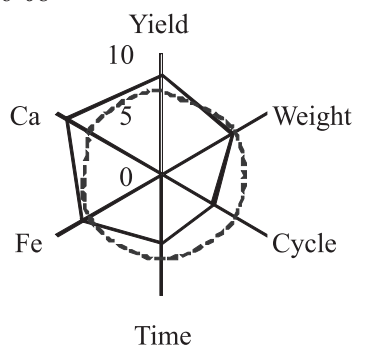

$\bar{Z}$ index Average

Figure 1. $\bar{Z}$ indices and average $(n=7)$ for cycle, weight of 100 grains (weight), grain yield (yield), cooking time (time) and calcium $(\mathrm{Ca})$ and iron $(\mathrm{Fe})$ concentrations in grains of nine inbred common bean lines with the highest $\bar{Z}$ index average estimates for all traits.

\section{Conclusions}

1. Inbred common bean lines show genetic variability for cycle, weight of 100 grains, grain yield, cooking time, and calcium and iron concentrations in grains.

2. The DF 06-09 and DF 06-03 lines have high agronomic performance and high iron concentration in grains.

3. The DF 06-17 and DF 06-08 lines have high agronomic performance and high calcium concentration in grains.

\section{Acknowledgements}

To Fundação de Amparo à Pesquisa do Estado do Rio Grande do Sul (Fapergs), for financial support and scholarships granted; to Conselho Nacional de Desenvolvimento Científico e Tecnológico (CNPq) and to Coordenação de Aperfeiçoamento de Pessoal de Nível Superior (Capes), for grants awarded.

\section{References}

AKOND, A.S.M.G.M.; CRAWFORD, H.; BERTHOLD, J.; TALUKDER, Z.I.; HOSSAIN, K. Minerals (Zn, Fe, Ca and $\mathrm{Mg}$ ) and antinutrient (phytic acid) constituents in common bean. American Journal of Food Technology, v.6, p.235-243, 2011. DOI: 10.3923/ajft.2011.235.243.

BEEBE, S.; GONZALEZ, V.; RENGIFO, J. Research on trace minerals in the common bean. Food and Nutrition Bulletin, v.21, p.387-391, 2000.

BLAIR, M.W.; ASTUDILLO, C.; GRUSAK, M.A.; GRAHAM, R.; BEEBE, S.E. Inheritance of seed iron and zinc concentrations 
in common bean (Phaseolus vulgaris L.). Molecular Breeding, v.23, p.197-207, 2009. DOI: 10.1007/s11032-008-9225-z.

BLAIR, M.W.; MEDINA, J.L.; ASTUDILLO, C.; RENGIFO, J.; BEEBE, S.E.; MACHADO, G.; GRAHAM, R. QTL for iron and zinc concentration and content in a Mesoamerican common bean (Phaseolus vulgaris L.) population. Theoretical and Applied Genetics, v.121, p.1059-1070, 2010. DOI: 10.1007/ s00122-010-1371-0.

BRASIL. Ministério da Agricultura, Pecuária e Abastecimento. Zoneamento agrícola de risco climático: cultivares de feijão - ano - safra 2011/2012. Brasília: MAPA, 2012. Disponível em: <http:// www.agricultura.gov.br/politica-agricola/zoneamento-agricola $>$. Acesso em: 30 jul. 2012.

BROUGHTON, W.J.; HERNANDEZ, G.; BLAIR, M.; BEEBE, S.; GEPTS, P.; VANDERLEYDEN, J. Beans (Phaseolus spp.): model food legumes. Plant and Soil, v.252, p.55-128, 2003. DOI: 10.1023/A:1024146710611.

BURATTO, J.S.; MODA-CIRINO, V.; FONSECA JÚNIOR, N. da S.; PRETE, C.E.C.; FARIA, R.T. de. Adaptabilidade e estabilidade produtiva em genótipos precoces de feijão no estado do Paraná. Semina: Ciências Agrárias, v.28, p.373-380, 2007. DOI: $10.5433 / 1679-0359.2007 \mathrm{v} 28 \mathrm{n} 3 \mathrm{p} 373$.

CICHY, K.A.; CALDAS, G.V.; SNAPP, S.S.; BLAIR, M.W. QTL analysis of seed iron, zinc, and phosphorus levels in an Andean bean population. Crop Science, v.49, p.1742-1750, 2009. DOI: 10.2135/cropsci2008.10.0605.

FERNÁNDEZ, F.; GEPTS, P.; LÓPEZ, M. Etapas de desarrollo de la planta de frijol común (Phaseolus vulgaris L.). Cali: CIAT, 1986. 34p.

JOST, E.; RIBEIRO, N.D.; CARGNELUTTI FILHO, A.; ANTUNES, I.F. Composição de macrominerais em cultivares de feijão e aplicações para o melhoramento genético. Pesquisa Agropecuária Gaúcha, v.16, p.31-38, 2010.

JOST, E.; RIBEIRO, N.D.; CERUTTI, T.; POERSCH, N.; MAZIERO, S.M. Potencial de aumento do teor de ferro em grãos de feijão por melhoramento genético. Bragantia, v.68, p.35-42, 2009a. DOI: 10.1590/S0006-87052009000100005.

JOST, E.; RIBEIRO, N.D.; MAZIERO, S.M.; CERUTTI, T.; ROSA, D.P. Efeitos gênicos do teor de cálcio em grãos de feijão. Ciência Rural, v.39, p.31-37, 2009b. DOI: 10.1590/ S0103-84782008005000055.

JOST, E.; RIBEIRO, N.D.; MAZIERO, S.M.; POSSOBOM, M.T.D.F.; ROSA, D.P.; DOMINGUES, L.S. Comparison among direct, indirect and index selections on agronomic traits and nutritional quality traits in common bean. Journal of the Science of Food and Agriculture, v.93, p.1097-1104, 2013. DOI: 10.1002/ jsfa.5856.

MENDES, F.F.; RAMALHO, M.A.P; ABREU, A. de F.B. Índice de seleção para escolha de populações segregantes de feijoeiro-comum. Pesquisa Agropecuária Brasileira, v.44, p.1312-1318, 2009. DOI: 10.1590/S0100-204X2009001000015.
MESQUITA, F.R.; CÔRREA, A.D.; ABREU, M.C.P. de; LIMA, R.A.Z.; ABREU, A. de F.B. Linhagens de feijão (Phaseolus vulgaris L.): composição química e digestibilidade protéica. Ciência e Agrotecnologia, v.31, p.1114-1121, 2007. DOI: 10.1590/ S1413-70542007000400026.

MIYAZAWA, M.; PAVAN, M.A.; MURAOKA, T.; CARMO, C.A.F.S.; MELLO, W.J. Análises químicas de tecido vegetal. In: SILVA, F.C. (Ed.). Manual de análises químicas de solos, plantas e fertilizantes. Brasília: Embrapa Comunicação para Transferência de Tecnologia, 1999. p.171-223.

PERINA, E.F.; CARVALHO, C.R.L.; CHIORATO, A.F.; GONÇALVES, J.G.R.; CARBONELL, S.A.M. Avaliação da estabilidade e adaptabilidade de genótipos de feijoeiro (Phaseolus vulgaris L.) baseada na análise multivariada da "performance" genotípica. Ciência e Agrotecnologia, v.34, p.398-406, 2010. DOI: $10.1590 / \mathrm{S} 1413-70542010000200018$.

RIBEIRO, N.D.; ANTUNES, I.F.; SOUZA, J.F. de; POERSCH, N.L. Adaptação e estabilidade de produção de cultivares e linhagens-elite de feijão no Estado do Rio Grande do Sul. Ciência Rural, v.38, p.2434-2440, 2008. DOI: 10.1590/ S0103-84782008005000018.

RIBEIRO, N.D.; CARGNELUTTI FILHO, A.; POERSCH, N.L.; ROSA, S.S. da. Padronização de metodologia para avaliação do tempo de cozimento dos grãos de feijão. Bragantia, v.66, p.335-348, 2007. DOI: 10.1590/S0006-87052007000200018.

RODRIGUES, J. de A.; RIBEIRO, N.D.; CARGNELUTTI FILHO, A.; TRENTIN, M.; LONDERO, P.M.G. Qualidade para o cozimento de grãos de feijão obtidos em diferentes épocas de semeadura. Bragantia, v.64, p.369-376, 2005a. DOI: 10.1590/ S0006-87052005000300006.

RODRIGUES, J. de A.; RIBEIRO, N.D.; LONDERO, P.M.G.; CARGNELUTTI FILHO, A.; GARCIA, D.C. Correlação entre absorção de água e tempo de cozimento de cultivares de feijão. Ciência Rural, v.35, p.209-214, 2005b. DOI: 10.1590/ S0103-84782005000100034.

SANTOS, H.G. dos; JACOMINE, P.K.T.; ANJOS, L.H.C. dos; OLIVEIRA, V.A. de; OLIVEIRA, J.B. de; COELHO, M.R.; LUMBRERAS, J.F.; CUNHA, T.J.F. (Ed.). Sistema Brasileiro de classificação de solos. 2.ed. Rio de janeiro: Embrapa Solos, 2006. $306 \mathrm{p}$.

SILVA, C.A.; ABREU, A. de F.B.; RAMALHO, M.A.P.; MAIA, L.G.S.M. Chemical composition as related to seed color of common bean. Crop Breeding and Applied Biotechnology, v.12, p.132-137, 2012. DOI: 10.1590/S1984-70332012000200006.

WELCH, R.M.; GRAHAM, R.D. Breeding for micronutrients in staple food crops from a human nutrition perspective. Journal of Experimental Botany, v.55, p.353-364, 2004. DOI: 10.1093/jxb/ erh064.

WHITE, P.J.; BROADLEY, M.R. Biofortifing crops with essential mineral elements. Trends in Plant Science, v.10, p.586-593, 2005. DOI: $10.1016 /$ j.tplants.2005.10.001.

Received on May 5, 2013 and accepted on September 20, 2013

Pesq. agropec. bras., Brasília, v.48, n.10, p.1368-1375, out. 2013 DOI: $10.1590 / \mathrm{S} 0100-204 X 2013001000008$ 